\title{
Oncogenic osteomalacia: strange tumours in strange places
}

\author{
Daniel Weiss ${ }^{1}$, Robert S. Bar ${ }^{1}$, Noel Weidner ${ }^{2}$, Mark Wener ${ }^{1}$ and Ferrol Lee ${ }^{1}$ \\ ${ }^{1}$ Veterans Administration Medical Center, Department of Internal Medicine, and ${ }^{2}$ Department of Pathology, \\ University of Iowa, Iowa City, Iowa.
}

\begin{abstract}
Summary: Two patients presented with hypophosphataemic osteomalacia and were subsequently found to have small tumours of unusual histopathology and location causing the osteomalacia. Each tumour was found after an intensive search for occult masses. Studies of vitamin D metabolism and renal tubular function before and after surgery yielded further insight into the pathophysiology of oncogenic osteomalacia. These cases demonstrate that microscopic quantities of tumour are capable of causing the syndrome and further illustrate the high index of suspicion often necessary to locate causative tumours in patients with hypophosphataemic osteomalacia.
\end{abstract}

\section{Introduction}

In 1947, McCance described a patient with dramatic resolution of chronic hypophosphataemia and severe osteomalacia after resection of a soft tissue tumour. Since then, at least 32 additional reports have described a similar clinical entity completely cured by tumour removal, a syndrome now referred to as oncogenic osteomalacia (Agus, 1983a; Fukumoto et al., 1979; Weidner et al., in press). Patients with oncogenic osteomalacia characteristically present with a low renal threshold for phosphate reabsorption (TmPO 4 /GFR) (Walton \& Bijvoet, 1975), hypophosphataemia, and osteomalacia. We now report two cases of oncogenic osteomalacia which detail the bizarre location, behaviour, and pathology of the tumours that can be associated with this disorder.

\section{Case reports}

\section{Case 1}

This white male was first seen in June 1978 at age 34 with a 1 year history of back stiffness and lower extremity weakness. On physical examination there was a wide-based shuffling gait. Plain films of the pelvis showed diffuse osteopenia. Serum phosphate was $0.52 \mathrm{mmol} / 1$ (normal $0.81-1.45 \mathrm{mmol} / \mathrm{l}$ ). There was no history of diarrhoea, alcohol abuse, antacid or diuretic use. By August 1978 his symptoms had

D. Weiss, M.D.; R.S. Bar, M.D.; N. Weidner, M.D.; M. Wener, M.D.; F. Lee, M.D.

Correspondence: Robert Bar, Associate Professor of Medicine, Veterans Administration Hospital, 3E-17, Internal Medicine, Iowa City, Iowa 52240

Accepted: 9 May 1984 progressed and he was forced to stop work as a postman. Physical examination then showed difficulty arising from a squatting position with decreased strength in his hip flexors and abductors. His gait was waddling with an abductor lurch to the left. A small $2 \times 3 \mathrm{~cm}$ firm non-tender immobile nodule on the mid-palmar surface of the left hand was noted (Figure 1), the patient believing this lesion had been present for at least 5 years. Laboratory evaluation at this time showed serum phosphate averaging $0.61 \mathrm{mmol} / 1$ (range $0.52-0.71$ ) with a consistently normal serum calcium $(2.35 \mathrm{mmol} / \mathrm{l})$. Alkaline phosphatase was 329 IU/1 (normal < 115) with a normal gamma glutamyl transpeptidase and aspartate amino-transferase. Arterial blood $\mathrm{pH}$ was 7.42, urine $\mathrm{pH} 6$, serum bicarbonate $26 \mathrm{mmol} / 1$, and urine $\mathrm{pH} 4.9$ after oral ammonium chloride loading. Twenty-four hour urines for amino acids and heavy metals were normal. No glycosuria was present and creatinine clearance was $123 \mathrm{ml} / \mathrm{min}$. Evaluation of $24 \mathrm{~h}$ urine collection showed uric acid $4.2 \mathrm{mmol}$, phosphate $24.5 \mathrm{mmol}$, and Calcium $3.9 \mathrm{mmol}$. Serum carotene, prothrombin time and $72 \mathrm{~h}$ fecal fat were normal. Immunoreactive parathyroid hormone level (intact) (UpJohn Labs, Kalamazoo, Michigan) was normal at $226 \mathrm{pgeq} / \mathrm{ml}$ (normal 163-347). Vitamin D determinations (courtesy Dr H. DeLuca, Madison, Wisconsin) showed normal $25-\mathrm{OH} \mathrm{D}_{2+3}(29 \mathrm{ng} / \mathrm{ml})$, undetectable 1,25 $(\mathrm{OH})_{2} \mathrm{D}_{3}$, and elevated $24,25-(\mathrm{OH})_{2} \mathrm{D}_{3}$ of $8.6 \mathrm{ng} / \mathrm{ml}$ (normal 0.25-2.5). Bone scan in September 1978 demonstrated intense radiotracer ${ }^{99 \mathrm{~m}}$ Technetium methylene diphosphonate) uptake corresponding to the left hand mass. Plain hand films were normal. Rib biopsy after tetracycline labelling displayed markedly widened osteoid seams and decreased trabeculae 


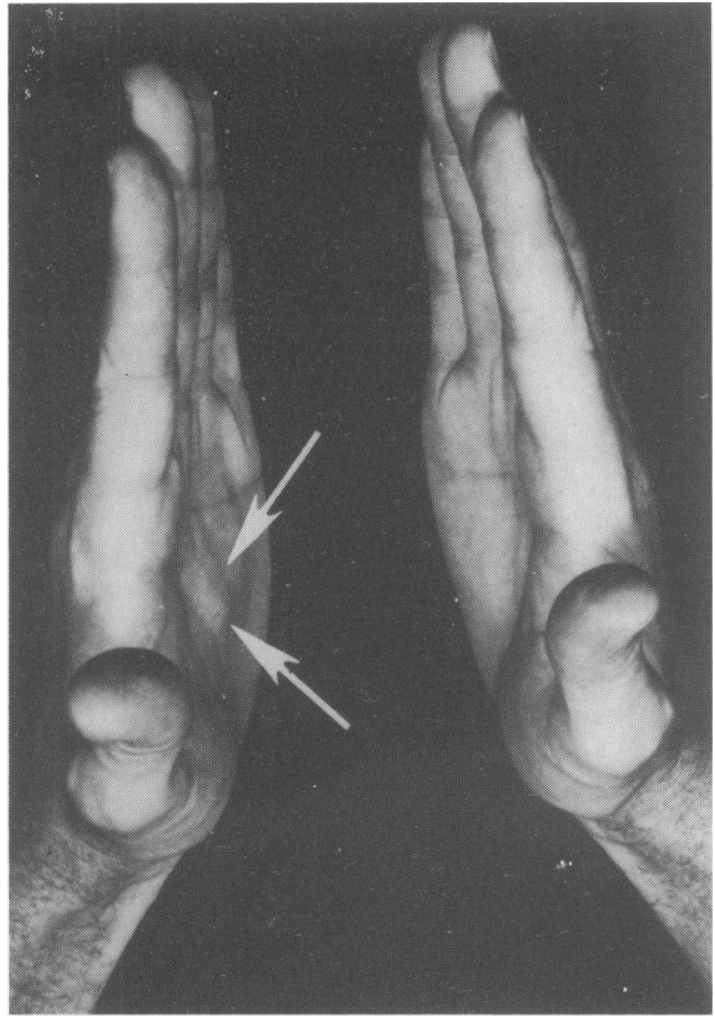

Figure 1 The appearance of tumour before surgery: Case 1, a mass on palm of left hand.

characteristic of severe osteomalacia. Surgery was performed on the left hand lesion in October 1978 with the removal of a $3.5 \times 2.5 \times 1.5 \mathrm{~cm}$ white encapsulated tumour located just beneath the flexor tendons without attachment to surrounding structures. Histologic examination revealed a tumour composed of poorly developed hyaline cartilage and osteoclast-like giant cells (Figure 2). The latter were frequently found within prominent fibrovascular channels. Detailed pathological studies are reported separately (Weidner et al., in press). Serum phosphate, which was $0.55 \mathrm{mmol} / \mathrm{l}$ pre-operatively, rose to 0.81 in $24 \mathrm{~h}$. Three months later the patient returned to work as a postman having had complete resolution of bone pain and muscle weakness. Physical examination at that time demonstrated normal gait and muscle strength. Serum phosphate was $1.4 \mathrm{mmol} / \mathrm{l}$. One year postoperatively vitamin $\mathrm{D}$ determinations demonstrated normal serum levels of $1,25-(\mathrm{OH})_{2} \mathrm{D}_{3}(79 \mathrm{pg} / \mathrm{ml})$ and $25-\mathrm{OH} \mathrm{D}_{3}(39 \mathrm{ng} / \mathrm{ml})$. Follow up at 20 months postoperatively showed no recurrence of symptoms and a serum phosphate of $1.2 \mathrm{mmol} / \mathrm{l}$.

\section{Case 2}

This 39 year old white female was initially evaluated in August 1981 with an 18 month history of fatigue, lower extremity weakness, and foot and low back pain. There was no history of diarrhoea, antacid or diuretic use or ethanol abuse. Physical examination revealed a waddling gait and proximal muscle weakness. Serum phosphate was $0.52-0.58 \mathrm{mmol} / 1$ (normal $0.81-1.45$ ) with $24 \mathrm{~h}$ urinary phosphate of $15.4 \mathrm{mmol}$. Serum calcium was normal $(2.3 \mathrm{mmol} / \mathrm{l})$ with normal levels of immunoreactive parathyroid hormone on two occasions: 63 and $69 \mu \mathrm{leq} / \mathrm{ml}$ (normal 20-70, Mayo Labs, Rochester, Minnesota). Twenty-five hydroxy vitamin $\mathrm{D}_{3}$ level was normal on two different determinations and serum $1,25(\mathrm{OH})_{2} \mathrm{D}_{3}$ was low at $10 \mathrm{pg} /$ ml (normal 20-76, BioScience Labs, Van Nuys, California). Alkaline phosphatase was elevated at 132 IU/l (normal $<115$ ) and $24 \mathrm{~h}$ urinary hydroxyproline was $446 \mu \mathrm{mol}$ (normal < 190). Urinalysis and serum electrolytes were normal. Creatinine clearance was $107 \mathrm{ml} / \mathrm{min}$. There was no glycosuria and urine for heavy metals was negative. She was begun on oral phosphate $(64 \mathrm{mmol}$ of elemental phosphorus/day) with no improvement in her serum phosphate or her symptoms. In January 1982 a rib biopsy obtained after tetracycline labelling demonstrated markedly widened osteoid seams characteristic of osteomalacia. A com puterized tomographic (CT) scan of the lumbosacrat spine showed a bone density of $90 \mathrm{mg}$ of dipotassiurn hydrogen phosphate (greater than 2 s.d. below that for age-matched controls). Despite the addition of vitamin D, initially as ergocalciferol 25000 units a day, then as calcitriol $0.75 \mu \mathrm{g} / \mathrm{d}$, her symptoms worsened and her serum phosphate remained low. She was not seen again until May 1983 by which time she was confined to a wheelchair because of progressive lower extremity weakness and pain. On repeat CT scan of the spine there was a slight decrement in bone density to $85 \mathrm{mg}$ of dipotassium hydrogen phosphate.

In August 1983 she was hospitalized with the goal of optimizing her calcitriol and phosphate therapy and searching for an occult tumour possibly causing the osteomalacia. Prothrombin time, serum vitamin $\mathbf{B}_{12}$, serum carotene, $5 \mathrm{~h}$ xylose absorption, and $72 \mathrm{~h}$ fecal fat were all normal. Twenty-four hour urine for amino acids was normal. Chest X-ray and plain films of the upper and lower extremities showed only diffuse osteopenia. CT scans of the brain, chest, abdomen, and pelvis were normal. Plain films of the paranasal sinuses showed an abnormality in the right maxillary sinus interpreted by both radiology and otolaryngology consultants as a benign mucous retention cyst (Figure 3). Calcitriol, $3.5 \mu \mathrm{g} / \mathrm{d}$, and oral phosphate had produced no serum phosphate higher than $0.77 \mathrm{mmol} / 1$ and no change in symptoms. Because of the failure to respond to medical therapy, surgical 


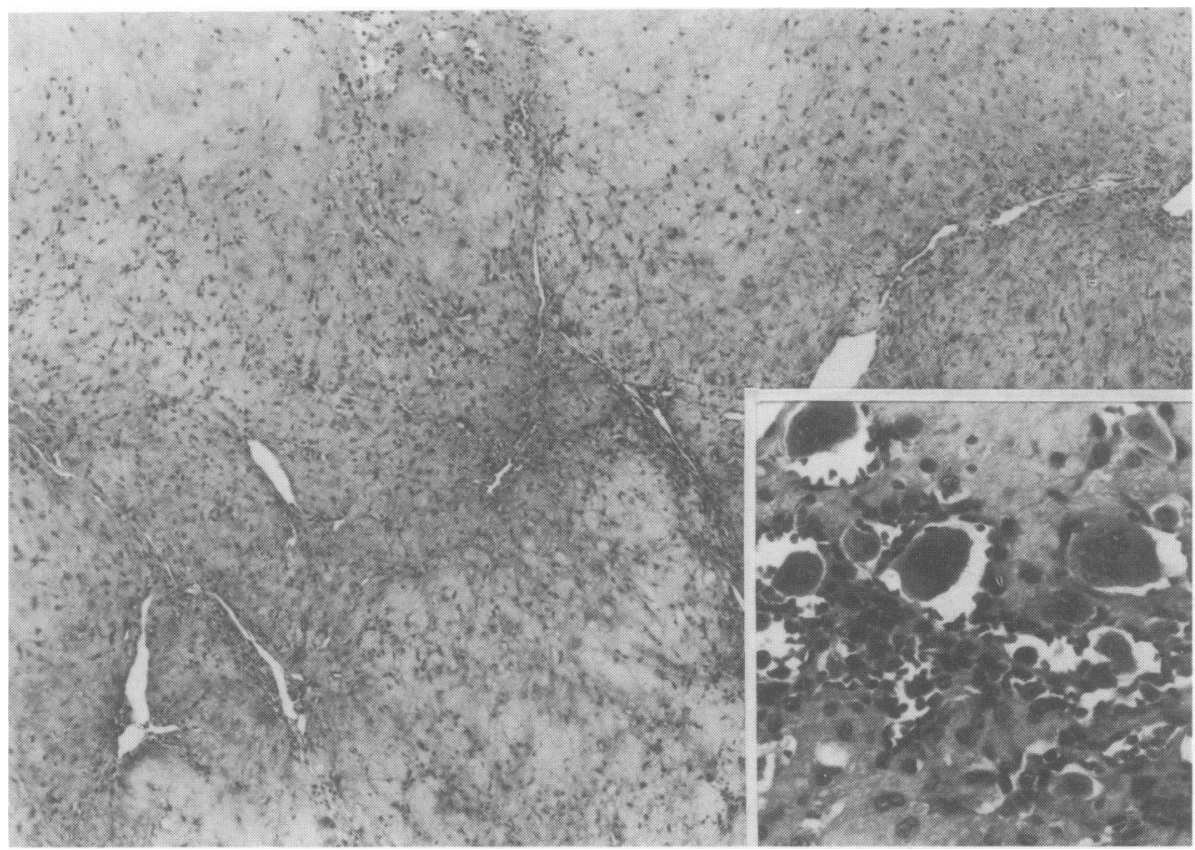

Figure 2 Giant cell variant of soft part chondroma removed from palm of Case 1. Hypocellular cartilagenous matrix is transected by fibrovascular trabeculae containing focal clusters of osteoclast-like, multinucleated giant cells (original magnification $\times 10$ ). Inset shows the osteoclast-like, giant cells frequently lying within vascular spaces (original magnification $\times 160$ ).

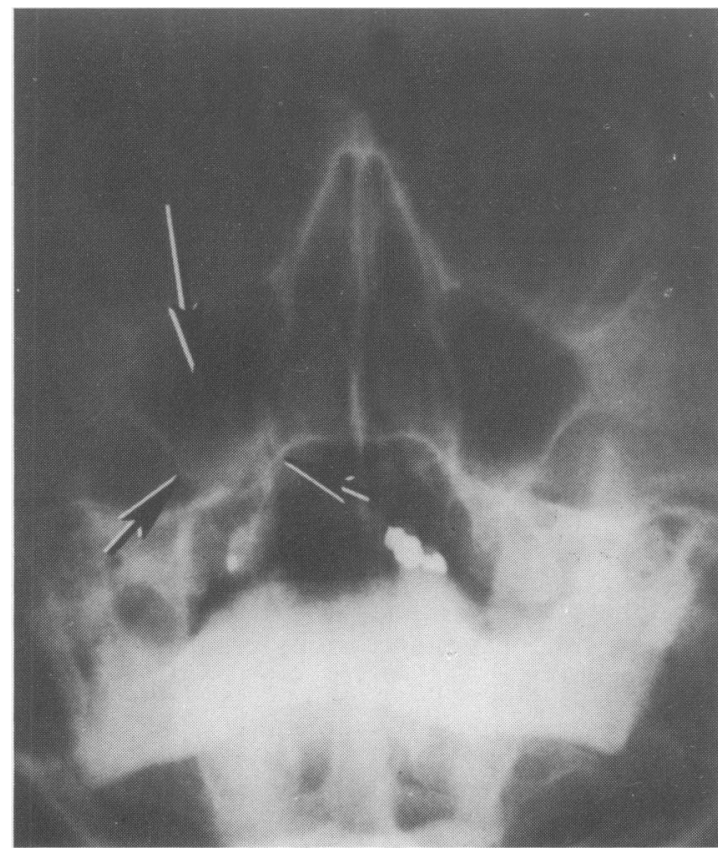

Figure 3 The appearance of tumour before surgery: Case 2, lesion in maxillary sinus. removal of the maxillary lesion was attempted via a Caldwell-Luc procedure. Calcitriol and phosphate therapy was stopped 5 days before surgery at which time the serum phosphate was $0.71 \mathrm{mmol} / 1$. At surgery, a $4 \times 3 \mathrm{~cm}$ reddish brown mass was found arising from the floor of the maxillary sinus and extending into the infratemporal fossa. The bulk of the tumour was resected. Histological examination showed a neoplasm composed of small undifferentiated mesenchymal cells and osteoclast-like giant cells (Figure 4). There was prominent vascularity and close association of the osteoclast-like cells to blood vessels. The small primitive mesenchymal cells were organelle-poor, containing few rough endoplasmic reticulum and specifically lacking in neurosecretory granules. The osteoclast-like giant cells were organelle rich with abundant mitochondria, polyribosomes and rough endoplasmic reticulum. A descriptive diagnosis of primitive mesenchymal tumour with prominent vascular and giant cell components was made. Detailed pathological studies, as with Case 1 , are reported elsewhere. Although serum phosphate transiently fell immediately after surgery, within $24 \mathrm{~h} \mathrm{TmPO} /$ /GFR (normal $2.5-4.5 \mathrm{mg} / \mathrm{dl} ; 0.81-1.45 \mathrm{mmol} / \mathrm{l}$ ) (Walton \& Bijvoet, 1975) and $1,25-(\mathrm{OH})_{2} \mathrm{D}_{3}$ levels began to rise (Figure 5). By 4-5 days postoperatively the patient noted improvement in her strength and a diminution 


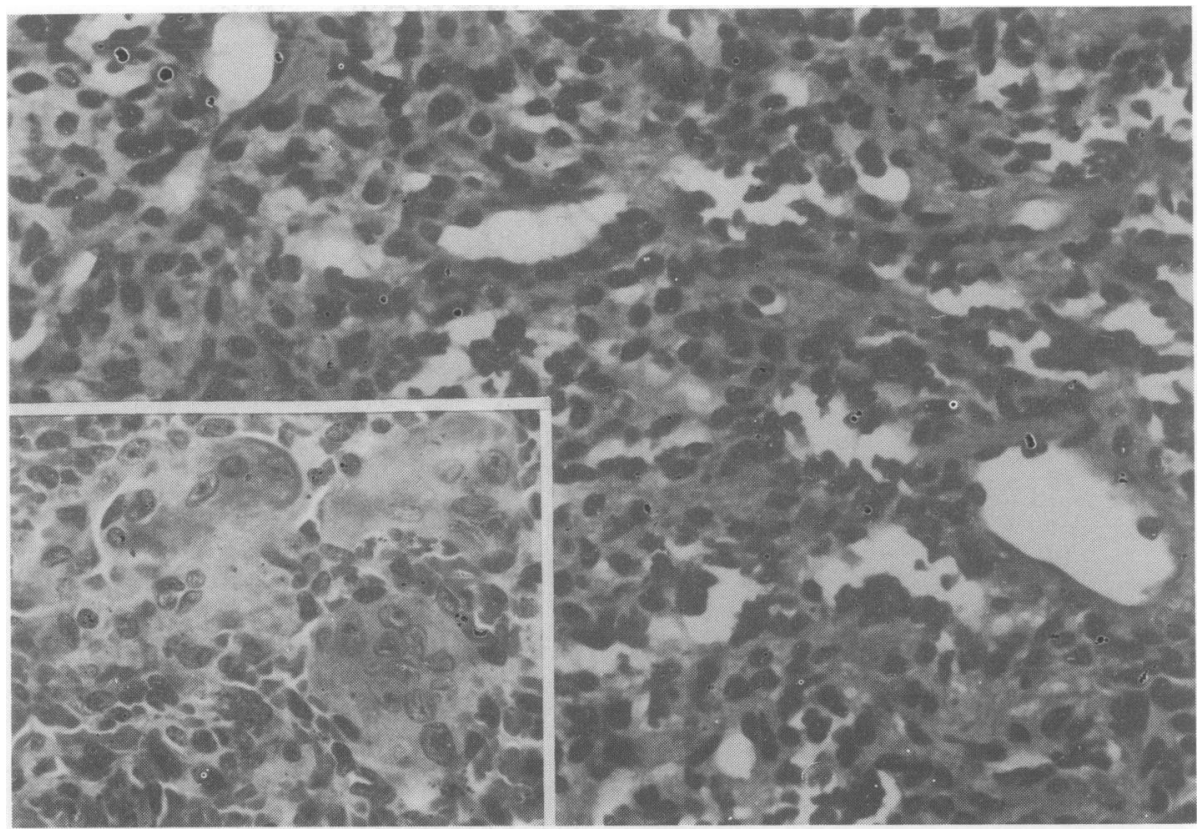

Figure 4 Primitive mesenchymal tumour with prominent vascular and giant cell components removed from the maxillary sinus of Case 2 . Small undifferentiated mesenchymal cells are separated by numerous vascular channels (original magnification $\times 100$ ). Inset shows cluster of osteoclast-like, multinucleated giant cells found scattered through the neoplasm (original magnification $\times 400$ ).

of her pain. She was discharged taking no medications with a serum phosphate of $0.97 \mathrm{mmol} / 1$. By one week postoperatively she was walking with minimal use of a walker. She was doing well one month after surgery walking without aids and exercising on a stationery bicycle. However, by 5 weeks postoperatively her serum phosphate fell below normal. One week later as her symptoms of weakness and fatigue recurred, she became unable to bicycle as she had when her phosphate was normal, and she began to use a walker again for ambulation. Evaluation at 10 weeks after surgery showed normal serum electrolytes and serum phosphate $0.52 \mathrm{mmol} / 1$. TmPO $/$ GFR was $1.2 \mathrm{mg} / \mathrm{dl}$ $(0.39 \mathrm{mmol} / \mathrm{l})$. In a $24 \mathrm{~h}$ urine collection there was phosphate $18.2 \mathrm{mmol}$, uric acid $3.1 \mathrm{mmol}$, glucose less than $0.5 \mathrm{mmol}$, and total protein less than $100 \mathrm{mg}$. There was $42 \mu \mathrm{g}$ of beta-2 microglobulin per $24 \mathrm{~h}$ (normal $<500 \mu \mathrm{g}$, Specialty Labs, Los Angeles, California). Twenty-four hour urine for amino acids was normal with borderline high valine excretion. After an oral ammonium chloride loading test she was able to acidify her urine to $\mathrm{pH} 4.66$. Serum $25-\mathrm{OH} \mathrm{D}_{3}$ was again normal at $14 \mathrm{ng} / \mathrm{ml}$. At this time the serum $1,25(\mathrm{OH})_{2} \mathrm{D}_{3}$ was also normal at $32 \mathrm{pg} / \mathrm{ml}$.

On November 18, 1983 she underwent transantral exploration of the right maxillary sinus and pterygoid fossa. Fibrovascular reactive tissue was found with scattered microscopic foci of small, undifferentiated neoplastic cells having an estimated weight of 2-4 mg These small foci were histologically similar to the original tumour except that osteoclast-like, multinucleated giant cells were scant to absent. Twelve hours after surgery her serum phosphate and electrolytes were unchanged. Twenty-four hours postoperatively, phosphate had fallen to $0.35 \mathrm{mmol} / 1$, sodium was 137 , chloride 109 , potassium 3.2 , and $\mathrm{CO}_{2} 16$. This picture of a hypokalaemic hyperchloraemic normal anion gap metabolic acidosis resolved over the next 36 hours. Serum phosphate remained low until the sixth postoperative day by which time it rose to $0.84 \mathrm{mmol} / 1$. Tubular reabsorption of phosphate was $94 \%$ with $\mathrm{TmPO}_{4} / \mathrm{GFR}$ of $2.95 \mathrm{mg} / \mathrm{dl}(0.95 \mathrm{mmol} / \mathrm{l})$. By day 10 , serum $1,25(\mathrm{OH})_{2} \mathrm{D}_{3}$ was $196 \mathrm{pg} / \mathrm{ml}$, two and a half times the upper limit of normal. Serum phosphate continued to rise to $1.0 \mathrm{mmol} / 1$ on the eleventh postoperative day, 1.23 by day 18 , and 1.55 on day 25 . At the time of this writing the patient remains well, walking without assistance with a serum phosphate of $1.48 \mathrm{mmol} / \mathrm{l}$.

\section{Discussion}

These two cases manifest several clinical features which typify oncogenic osteomalacia. In previously reported cases, symptoms of bone pain and progres- 

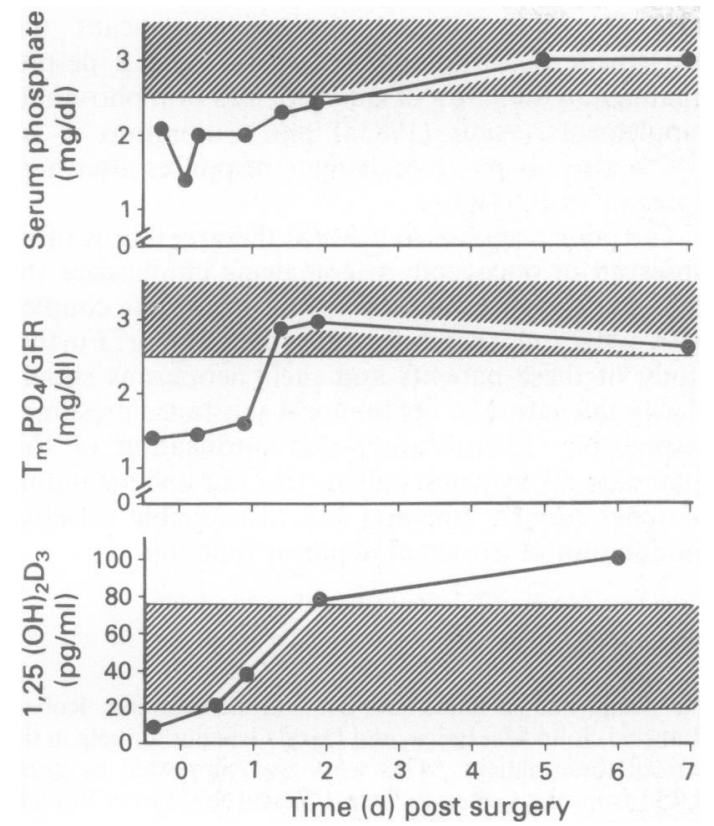

Figure 5 Course of Case 2 before and after initial surgery. Shaded area indicates lower normal range for serum phosphate (inorganic phosphorus) and $\mathrm{TmPO}_{4} /$ GFR and entire normal range for serum $1,25(\mathrm{OH})_{2} \mathrm{D}_{3}$. To convert $\mathrm{mg} / \mathrm{dl}$ phosphorus to $\mathrm{mmol} / \mathrm{dl}$ divide by 3.1 .

sive weakness were present from one to as many as 13 years (Linovitz et al., 1976) before the tumour is found. There is sustained hypophosphataemia with a low renal phosphate threshold and therefore marked renal phosphate wasting. There may be associated aminoaciduria (Fukumoto et al., 1979; Evans \& Azzopardi, 1972; Drezner \& Feinglos, 1977) or mild glycosuria. Other findings associated with proximal tubular dysfunction such as hyperuricosuria or impaired urinary acidification have not been found. Serum levels of parathyroid hormone, calcium and 25$\mathrm{OH}$ vitamin $\mathrm{D}$ are normal whereas the $1,25-(\mathrm{OH})_{2} \mathrm{D}_{3}$ level is uniformly low (Agus, 1983a; Drezner et al., 1982; Drezner and Feinglos, 1977; Fukumoto et al., 1979; Lau et al., 1979; Sweet et al., 1980). Complete resolution of the clinical and metabolic abnormalities occurs upon removal of the tumour.

Two main obstacles to cure exist. First, this condition must be suspected in the patient presenting with hypophosphataemia and inappropriate phosphaturia. Second, the suspicion must be high enough to encourage a vigorous search for the offending neoplasm. Our two cases of oncogenic osteomalacia illustrate important clinical aspects of these tumours. First they can be small in size. Indeed, this meant a microscopic focus in Case 2 at the time of repeat surgery. Furthermore, they can occur in unusual locations and can be confused with common benign lesions. Therefore, there are significant potential problems in not only identifying these tumours, but often in recommending surgical intervention.

Among the features of our 2 cases that have been rarely described in previous cases of oncogenic osteomalacia is the elevated level of $24,25(\mathrm{OH})_{2} \mathrm{D}_{3}$ in Case 1. This vitamin D metabolite was normal in the single instance that it was reported in the literature (Sweet et al., 1980). Another feature in Case 1 is the striking tumour uptake of radiotracer on bone scan. Although this has never before been reported, this imaging technique may be of value in localization of the causative tumour.

A variety of tumours have been associated with oncogenic osteomalacia. Among the most common are ossifying mesenchymal tumour, osteoblastoma, hemangiopericytoma-like tumour and nonossifying fibroma. Despite the apparent wide range of tumour type, analysis of the literature shows that approximately $80 \%$ were reported to have prominent vascularity and osteoclast-like multinucleated giant cells (Weidner et al., in press). Light microscopic study in our cases showed intimate spatial relationship between these two components. In the cases described here, the osteoclast-like cells were rich in endoplasmic reticulum whereas other cells, at least in Case 2, had few cytoplasmic organelles, suggesting that these cells were not actively involved in significant protein synthesis. The fact that all biochemical defects rapidly reversed with complete tumour removal points toward the secretion of one or more causative substances secreted by the tumour tissue. That such substances are likely to be quite potent is evidenced by the hypophosphatemia in Case 2 caused by a microscopic residuum of tumour. Indeed, saline extracts from tumour of three different patients with oncogenic osteomalacia (Lau et al., 1979; Aschinberg et al., 1977; Popovtzer, 1981) have caused a decrease in tubular reabsorption of phosphate when injected into experimental animals.

The dramatic postoperative course of serum phosphate and $1,25(\mathrm{OH})_{2} \mathrm{D}_{3}$ seen in Case 2 (Figure 3) has been described only once before in the literature (Sweet et al., 1980). We have shown, in addition, that although serum phosphate may fall shortly after surgery, the $\mathrm{TmPO}_{4} / \mathrm{GFR}$ and $1,25(\mathrm{OH})_{2} \mathrm{D}_{3}$ level begin a steady rise $24 \mathrm{~h}$ after tumour removal, preceding the rise in serum phosphate. This finding strongly supports the existence of a circulating substance which depresses renal phosphate reabsorption threshold and in turn lowers serum phosphate. Any unifying explanation of the pathophysiology of the phosphaturia, however, must also account for the aminoaciduria and glycosuria seen in some patients and the low serum levels of $1,25-(\mathrm{OH})_{2} \mathrm{D}_{3}$. An agent which alters proximal nephron function to a varying extent could 
explain all of these findings. The proximal nephron is not only the site of reabsorption of glucose and amino acids, but is also the locus for most phosphate reabsorption (Agus, 1983b) and all $25-\mathrm{OH} \mathrm{D}_{3}-1 \alpha$ hydroxylase activity (Kawashima et al., 1981). The more pronounced hypophosphataemia and hypokalaemic hyperchloraemic metabolic acidosis that occurred shortly after the second surgery in Case 2 may have reflected a further impairment of proximal tubular function. It is interesting to postulate that an increased release of a substance(s) from the tumour tissue disrupted during surgical manipulation augmented proximal tubular dysfunction, perhaps producing a transient proximal renal tubular acidosis.

A renal phosphate leak alone cannot explain the biochemical abnormalities in oncogenic osteomalacia, especially in view of the stimulation of renal-1 $\alpha$-hydroxylase activity expected with phosphate depletion (Baxter \& DeLuca, 1976; Rader et al., 1979). Conversely, there is little convincing evidence showing direct effects of $1,25-(\mathrm{OH})_{2} \mathrm{D}_{3}$ on renal phosphate handling in humans (Bordier et al., 1978; Levine et al., 1978). Although Drezner et al. (1977) showed normalization of all biochemical abnormalities after high dose 1.25-

\section{References}

AGUS, Z.S. (1983a). Oncogenic hypophosphatemic osteomalacia. Kidney International, 24, 113.

AGUS, Z.S. (1983b). Renal handling of phosphate. In Textbook of Nephrology S.G. Massry \& R.J. Glassock, (eds) 3, p. 89, Williams and Wilkins: Baltimore, Maryland.

ASCHINBERG, L., SOLOMON, L., ZEIS, P.M., JUSTICE, P. \& ROSENTHAL, I.M. (1977). Vitamin D-resistant rickets associated with epidermal nevus syndrome: Demonstration of a phosphaturic substance in the dermal lesions. Journal of Pediatrics, 91, 56.

BAXTER, L.A. \& DeLUCA, H.F. (1976). Stimulation of 25hydroxyvitamin $\mathrm{D}_{3}$-l $\alpha$-hydroxylase by phosphate depletion. Journal of Biological Chemistry, 251, 3158.

BORDIER, P., RASMUSSEN, H., MARIE, P., MIRAVET, L., GUERIS, J. \& RYCKWAERT, A. (1978). Vitamin D metabolites and bone mineralization in man. Journal of Clinical Endocrinology and Metabolism, 46, 284.

DREZNER, M.K., LOBAUGH, K.W., LYLES, K.W., CAREY, D.E., PAULSON, D.F. \& HARRELSON, J.M. (1982). The pathogenesis and treatment of tumor-induced osteomalacia. In Vitamin D, Chemical, Biochemical and Clinical Endocrinology of Calcium Metabolism. Proceedings of the Fifth Workshop on Vitamin D, A.W. Norman, K. Schaefer, D. von Herrath \& H-G. Grigoleit (eds), p. 950, Walter de Gruyter and Co: Berlin.

DREZNER, M.K. \& FEINGLOS, M.N. (1977). Osteomalacia due to $1 \alpha-25$-Dihydroxycholecalciferol deficiency. Association with a giant cell tumor of bone. Journal of Clinical Investigation, 60, 1046.

EVANS, D.J. \& AZZOPARDI, J.G. (1972). Distinctive tumors of bone and soft tissue causing acquired vitamin-D resistant osteomalacia. Lancet, i, 353.
$(\mathrm{OH})_{2} \mathrm{D}_{3} \quad(3.0 \mu \mathrm{g} / \mathrm{d})$, we saw no significant improvement in serum phosphate in Case 2 despite treatment with $3.5 \mu \mathrm{g}$ of calcitriol and oral phosphate supplements. Agus (1983a) and Fukumoto et al. (1979) also observed inadequate responses after high doses of $1 \alpha-(\mathrm{OH}) \mathrm{D}_{3}$.

The poor response to medical therapy that is often observed in oncogenic osteomalacia emphasizes the need for greater awareness of this syndrome coupled with a vigorous search for causative tumour. Further study of these patients and their neoplasms should clarify the nature of the humoral substance presumed responsible. Identification and purification of this material is likely to not only further our understanding of renal tubular function but also enable selective modulation of proximal nephron function.

\section{Acknowledgements}

We would like to thank Drs M. Paul Strottmann, Robert Bumsted, John MacIndoe, and Daryl Granner for help in the $\dot{\omega}$ care of these patients. This work was supported by grant $\overrightarrow{0}$ RR59 from the General Clinical Research Centers Branch, National Institutes of Health.
FUKUMOTO, Y., TARUI, S., TSUKIYAMA, K., ICHIHARA, K MORIWAKI, K., NONAKA, K., MIZUSHIMA, T., KOBAYĀ̄ SHI, Y., DOKOH, S., FUKUNAGA, M. \& MORITA, R. (1979 Tumor-induced vitamin D-resistant hypophosphatemic osteomalacia associated with proximal renal tubular dysfunction and 1,25 dihydroxyvitamin D deficiency. Journal of Clinical Endocrinology and Metabolism, 49, 873.

KAWASHIMA, H., TORIKAI, S. \& KUROKAWA, K. (1981). Localization of 25-hydroxyvitamin $\mathrm{D}_{3}-1 \alpha$-hydroxylase and 24-hydroxylase along the rat nephron. Proceedings of the National Academy of Sciences, 78, 1199.

LAU, K., STOM, M.C., GOLDBERG, M., GOLDFARB, S., GRAY, R., LEMANN, J. \& AGUS, Z.S. (1979). Evidence for a humoral phosphaturic factor in oncogenic hypophosphatemic osteomalacia. Clinical Research, 27, 421A (abstract).

LEVINE, B.S., BRAUTBAR, N. \& COBURN, J.W. (1978). Does vitamin $\mathrm{D}$ affect the renal handling of calcium and phosphorus? Mineral and Electrolyte Metabolism, 1, 295.

LINOVITZ, R.J., RESNICK, D., KEISSLING, P., KONDON, J.J., D SEHLER, B., NEJDL, R.J., ROWE, J.H. \& DEFTOS, L.J. 兰. (1976). Tumor-induced osteomalacia and rickets. A sur- $\bar{N}$ gically curable syndrome. Journal of Bone and Joint Surgery, 58A, 419.

MCCANCE, R.A. (1947). Osteomalacia with Looser's nodes $N$ (Milkman's Syndrome) due to raised resistance to vitamin D acquired about the age of 15 years. Quarterly Journal of Medicine, 16, 33.

POPOVTZER, M.M. (1981). Tumor-induced hypophosphatemic osteomalacia. Evidence for a phosphaturic cyclic AMP-independent action of tumor extract. Clincial $\mathbf{R e}$ search, 29, 418A (abstract). 
RADER, J.I., BAYLINK, D.J., HUGHES, M.R., SAFILIAN, E.F. \& HAUSSLER, M.R. (1979). Calcium and phosphorus deficiency in rats. Effects on PTH and 1,25-dihydroxyvitamin $\mathrm{D}_{3}$. American Journal of Physiology, 236, E118. SWEET, R.A., MALES, J.L., HAMSTRA, A.J. \& DELUCA, H.F. (1980). Vitamin D metabolite levels in oncogenic osteomalacia. Annals of Internal Medicine, 93, 279.
WALTON, R.J. \& BIJVOET, O.L.M. (1975). Nomogram for the derivation of renal threshold phosphate concentration. Lancet, ii, 309.

WEIDNER, N., BAR, R.S., WEISS, D. \& STROTTMANN, M.P. (1985). Neoplastic pathology of oncogenic osteomalacia/ rickets. Cancer, (in press). 